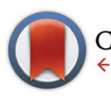

CrossMark \& click for updates

Cite this: Food Funct., 2016, 7, 2223

\title{
Chemical characterization and bioactive properties of two aromatic plants: Calendula officinalis L. (flowers) and Mentha cervina L. (leaves)
}

\author{
María Miguel, ${ }^{a}$ Lillian Barros, ${ }^{\text {a,b }}$ Carla Pereira, ${ }^{a, c}$ Ricardo C. Calhelha, ${ }^{a, d}$ \\ Pablo A. Garcia, ${ }^{e} M^{a}$ Ángeles Castro, ${ }^{e}$ Celestino Santos-Buelga ${ }^{c}$ and \\ Isabel C. F. R. Ferreira*a
}

\begin{abstract}
The chemical composition and bioactive properties of two plants (Calendula officinalis L. and Mentha cervina L.) were studied. Their nutritional value revealed a high content of carbohydrates and low fat levels, and very similar energy values. However, they presented different profiles in phenolic compounds and fatty acids; $C$. officinalis presented mainly glycosylated flavonols and saturated fatty acids, while M. cervina presented mainly caffeoyl derivatives and polyunsaturated fatty acids. M. cervina showed the highest concentration of phenolic compounds while C. Officinalis presented higher amounts of sugars, organic acids and tocopherols. The highest antioxidant and cytotoxic activities were obtained for the hydromethanolic extract of $M$. cervina, which presented the lowest values of $\mathrm{EC}_{50}$ and exhibited cytotoxicity against the four tumor cell lines tested. Infusions showed no cytotoxicity for the tumor cell lines, and none of the extracts showed toxicity against non-tumor cells. This study contributes to expand the knowledge on both natural sources and therefore their use.
\end{abstract}

Received 20th March 2016 . Accepted 8th April 2016

DOI: $10.1039 / c 6 f o 00398 b$ www.rsc.org/foodfunction the quality, effectiveness and safety of these products, by expanding their knowledge and research. ${ }^{1,2}$

Calendula officinalis L (Asteraceae), commonly known as (pot) marigold, is an aromatic, erect, annual herb with yellow to orange flowers, used in the Mediterranean region since the time of the ancient Greeks and also known in the Indian and Arabic cultures; it is cultivated for ornamental and medicinal purposes. It is widely used in cosmetics, perfumes, pharmaceutical preparations, and food and as a colorant for natural fabrics such as wool, cotton, linen, hemp and silk. ${ }^{3,4}$ The use of flowers of marigold is reported in different folk medicines for external treatment of cuts, inflammations of the skin and oral mucosa, wounds and venous ulcers, as well as for the treatment of amenorrhoea, angina, fevers, gastritis, hypotension, jaundice, rheumatism and vomiting. ${ }^{5}$

According to the literature, the major constituents of C. officinalis included steroids, terpenoids, triterpenoids, phenolic acids, flavonoids and carotenoids. ${ }^{6}$ Several reports experimentally confirm the pharmacological activities of this plant and also of its isolated compounds, including anti-inflammatory, anti-edematous, anti-HIV, ${ }^{10}$ antibacterial and antifungal ${ }^{3}$ activities, and wound healing by in vivo assays ${ }^{7,8}$ and clinical trials in patients with head-and-neck cancer. ${ }^{9}$ Other reported activities include immuno-stimulating and immunomodulatory, ${ }^{11}$ spasmolytic, spasmogenic and gastroprotective, ${ }^{12,13}$ insecticidal, ${ }^{14}$ heart rate decrease,${ }^{15}$ cardioprotective, ${ }^{16}$ geno- 
toxic and antigenotoxic dose-dependent, ${ }^{17}$ antioxidant ${ }^{4,18-20}$ and antitumoral effects. ${ }^{7,21,22}$

Mentha cervina L. (Lamiaceae) also known as Hart's pennyroyal, is an aromatic herb, found mainly in Eurasia and Africa. This species of mint grows on edges of flooded areas, sometimes temporarily and has been cultivated in Central Europe since the sixteenth century, used as a medicinal herb in part because of its fine flavor. ${ }^{23}$ It is used traditionally as a food seasoning, mainly in fish recipes, fish soup, together with M. pulegium L. or as a substitute. It has also been used for its medicinal properties in the prevention of various gastric disorders and inflammation of the respiratory tract, and its essential oil has industrial applications in food conservation. ${ }^{24,25}$

The chemical composition of $M$. cervina essential oil has been reported to be constituted mainly by monoterpenoids (pulegone, isomenthone, menthone and limonene) with antibacterial and antifungal activities, resulting in an alternative of other mints for therapeutic purposes because of its lower level of pulegone, a terpenoid ketone which is toxic to the liver. ${ }^{25}$ The total phenolic content and total antioxidant capacity of M. cervina aqueous extract have been reported, and seven phenolic compounds have been identified (protocatechuic acid, $p$-coumaric acid, caffeic acid, chlorogenic acid, epicatechin, orientin and rutin). ${ }^{26}$

In the present work, $C$. officinalis and M. cervina were chemically characterized regarding their nutritional/energy values, free sugars, organic acids, fatty acids and tocopherols of the dry plants and their infusions, as commonly consumed preparations. Furthermore, the phenolic compounds and the bioactive properties (antioxidant and cytotoxic properties for tumor and non-tumor cells) of the hydromethanolic extracts and infusions of these plants were studied and compared. To the best of author's knowledge, the available data about the phytochemical characterization and bioactivity of these plants are limited, especially for M. cervina.

\section{Materials and methods}

\subsection{Plant material and preparation of the extracts}

C. officinalis (air-dried flowers) and M. cervina (air-dried leaves) samples were purchased from two companies, Soria Natural ${ }^{\circledR}$ from Soria, Spain, and Cantinho das Aromáticas ${ }^{\circledR}$ from Vila Nova de Gaia, Portugal, respectively. Both companies have their own organically grown crops. Each sample was reduced to a fine dried powder ( $20 \mathrm{mesh}$ ) and stored in a desiccator, protected from light, until further analysis.

To prepare the infusions, each sample ( $1 \mathrm{~g})$ was added to $200 \mathrm{~mL}$ of boiled distilled water and kept for resting at room temperature for $5 \mathrm{~min}$ followed by subsequent filtration through a Whatman No. 4 paper.

For hydromethanolic extract preparation, each sample $(1 \mathrm{~g})$ was extracted by stirring in $30 \mathrm{~mL}$ of methanol/water $(80: 20$ $\mathrm{v} / \mathrm{v}$, at $25{ }^{\circ} \mathrm{C}$ at $150 \mathrm{rpm}$ ) for $1 \mathrm{~h}$ and subsequently filtered through a Whatman paper No. 4. The residue was then extracted with an additional portion of $30 \mathrm{~mL}$ of the hydro- methanolic mixture. The combined extracts were evaporated under reduced pressure (rotary evaporator Büchi R-210, Flawil, Switzerland) until the complete removal of methanol, and afterwards the aqueous phase was frozen and lyophilized (FeeeZone 4.5, Labconco, Kansas City, MO, USA).

\subsection{Standards and reagents}

Acetonitrile (99.9\%), $n$-hexane (95\%) and ethyl acetate (99.8\%) were HPLC grade and obtained from Fisher Scientific (Lisbon, Portugal) and the other solvents used were of analytical grade and purchased from common sources. Water was obtained from a Millipore Direct-Q purification system (TGI Pure Water Systems, Greenville, SC, USA).

For the chemical characterization and antioxidant activity evaluation: the fatty acid methyl ester (FAME) reference standard mixture (standard 47885-U) was purchased from SigmaAldrich (St Louis, MO, USA), as also trichloroacetic acid (TCA), sugars, organic acids and Trolox (6-hydroxy-2,5,7,8-tetramethylchroman-2-carboxylic acid) standards. Phenolic compound standards were from Extrasynthese (Genay, France), tocol in $n$-hexane $\left(50 \mathrm{mg} \mathrm{mL} \mathrm{m}^{-1}\right)$ and tocopherols $(\alpha-, \beta-, \gamma$-, and $\delta$-isoforms) were purchased from Matreya (Plesant Gap, PA, USA), and 2,2-diphenyl-1-picrylhydrazyl (DPPH) was obtained from Alfa Aesar (Ward Hill, MA, USA).

For cytotoxic property evaluation: fetal bovine serum (FBS), L-glutamine, Hank's saline solution (HBSS), trypsin-EDTA (ethylenediaminetetraacetic acid), essential amino acids (2 $\mathrm{mM})$, penicillin/streptomycin solution $\left(100 \mathrm{U} \mathrm{mL}^{-1}\right.$ and $100 \mathrm{mg} \mathrm{mL}{ }^{-1}$, respectively), RPMI-1640 and DMEM culture media were from Hyclone (Logan, Utah, USA). Acetic acid, ellipticine, sulforhodamine B (SRB), trypan blue and tris[2amino-2-(hydroxymethyl)propane-1,3-diol)] were purchased from Sigma-Aldrich (St Louis, MO, USA).

\subsection{Chemical characterization of the plant dry material and infusions}

2.3.1. Nutritional and energy values. Ash, proteins, fat and carbohydrate contents (proximate composition) were analysed in the samples (dry plant and infusions), through standard procedures. ${ }^{27}$ To estimate the crude protein content $(\mathrm{N} \times 6.25)$ a macro-Kjeldahl method was applied; crude fat was determined by using a Soxhlet apparatus with petroleum ether; ash content was determined by incineration at $600 \pm 15{ }^{\circ} \mathrm{C}$ and total carbohydrates were calculated by difference. The energy value was calculated according to the following equation: Energy $(\mathrm{kcal})=4 \times(\mathrm{g}$ protein $+\mathrm{g}$ carbohydrate $)+9 \times(\mathrm{g}$ fat $)$. For infusion, total carbohydrates were calculated on the basis of total free sugars (section 2.3.2) and the energy value was calculated taking into account those results.

2.3.2. Free sugars. Free sugars were determined by high performance liquid chromatography coupled to a refraction index detector (HPLC-RI; Knauer, Smartline system 1000, Berlin, Germany), as previously described by the authors. ${ }^{28}$ Identification of sugar was made by comparing the relative retention times of sample peaks with standards ( $\mathrm{D}(-)$-fructose, $\mathrm{D}(+)$-glucose, $\mathrm{D}(+)$-sucrose, $\mathrm{D}(+)$-trehalose and $\mathrm{D}(+)$-xylose $)$ and 
quantification was based on the RI signal response of each standard, using the internal standard (IS, melezitose) method or the external standard method for infusions, and by using calibration curves obtained from the commercial standards of each compound. Results were expressed in $\mathrm{g}$ per $100 \mathrm{~g}$ of dry weight or in $\mathrm{g}$ per $100 \mathrm{~mL}$ of infusion.

2.3.3. Organic acids. Organic acids namely oxalic, quinic, malic, ascorbic and citric acids were determined following a procedure previously described by Barros et $a l^{28}$ and the analysis was performed by ultra-fast liquid chromatography coupled to photodiode array detection (UFLC-PDA; Shimadzu Corporation, Kyoto, Japan), using $215 \mathrm{~nm}$ and $245 \mathrm{~nm}$ (for ascorbic acid) as the preferred wavelengths; the quantification was performed by comparison of the area of the peaks recorded at the corresponding wavelength with calibration curves obtained from the commercial standards of each compound. The organic acids found were quantified by comparison of the area of their peaks with the calibration curves obtained from the commercial standards of each compound: oxalic acid $(y=$ $\left.9 \times 10^{6} x+377946 ; R^{2}=0.994\right) ;$ quinic acid $(y=612327 x+$ $\left.16563 ; R^{2}=1\right)$; malic acid $\left(y=863548 x+55591 ; R^{2}=0.999\right)$; ascorbic acid $\left(y=1 \times 10^{8} x+751815 ; R^{2}=0.999\right)$ and citric acid ( $\left.y=1 \times 10^{6} x+16276 ; R^{2}=1\right)$. The results were expressed in $\mathrm{mg}$ per $100 \mathrm{~g}$ of dry weight or in $\mathrm{mg}$ per $100 \mathrm{~mL}$ of infusion.

2.3.4. Tocopherols. Tocopherols were determined following a procedure previously described by Barros et al., ${ }^{28}$ using a HPLC system (Knauer, Smartline system 1000, Berlin, Germany) coupled to a fluorescence detector (FP-2020; Jasco, Easton, USA) programmed for excitation at $290 \mathrm{~nm}$ and emission at $330 \mathrm{~nm}$; the identification was performed by chromatographic comparisons with authentic standards $\left(\alpha-, \beta-, \gamma^{-}\right.$, and $\delta$-isoforms), while the quantification was based on the fluorescence signal response of each standard, using the IS (tocol) method and by using calibration curves obtained from the commercial standards of each compound. The results were expressed in $\mu \mathrm{g}$ per $100 \mathrm{~g}$ of dry weight or $\mu \mathrm{g}$ per $100 \mathrm{~mL}$ of infusion.

2.3.5. Fatty acids. Fatty acids were determined in the crude lipid fraction, after a trans-esterification process, by gas-liquid chromatography with flame ionization detection (GC-FID; DANI model GC 1000 instrument, Contone, Switzerland) as previously described by Barros et $a .^{28}$ Fatty acid identification was made by comparing the relative retention times of FAME peaks from samples with standards. The results were recorded and processed using Clarity Software (DataApex, Prague, The Czech Republic) and expressed as the relative percentage of each fatty acid.

\subsection{Phenolic compound characterization in the hydromethanolic extracts and infusions}

Chromatographic analyses were carried out on a Spherisorb S3 ODS-2 $\mathrm{C}_{18}$ column $(3 \mu \mathrm{m}, 4.6 \times 150 \mathrm{~mm}$, Waters, Milford, MA, EUA), thermostatted at $35{ }^{\circ} \mathrm{C}$. The mobile phase consisted of two solvents: (A) $0.1 \%$ formic acid in water and (B) acetonitrile, using a gradient as follows: $15 \%$ B for $5 \mathrm{~min}, 15 \%$ B to $20 \% \mathrm{~B}$ over $5 \mathrm{~min}, 20-25 \%$ B over $10 \mathrm{~min}, 25-35 \%$ B over $10 \mathrm{~min}$,
$35-50 \%$ B for $10 \mathrm{~min}$, and re-equilibration of the column, with

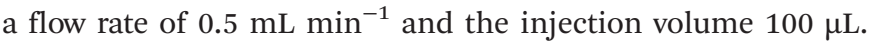
The spectral data for all peaks were recorded at 280 and $370 \mathrm{~nm}$ as preferred wavelengths. The HPLC-DAD-MS/ESI analyses were carried out using a Hewlett-Packard 1100 series chromatograph (Hewlett-Packard 1100, Agilent Technologies, Santa Clara, CA, USA) equipped with a diode-array detector (DAD) and a mass detector (API 3200 Qtrap, Applied Biosystems, Darmstadt, Germany) connected to the HPLC system via the PDA cell outlet. ${ }^{29}$ The identification of the different phenolic compounds was performed by comparison with available commercial standard compounds, or were tentatively identified using reported data from the literature. For quantitative analysis, a calibration curve for each available phenolic standard (caffeic acid, 5-O-caffeoylquinic acid, quercetin-3-Orutinoside, isorhamnetin-3-O-rutinoside, kaempferol-3-O-rutinoside, quercetin-3-O-glucoside, isorhamnetin-3-O-glucoside, rosmarinic acid) was constructed based on the UV signal or when no commercial standard was available, a similar compound from the same phenolic group was used as a standard. The results were expressed in $\mathrm{mg}$ per $\mathrm{g}$ of extract or $\mathrm{mg}$ per $\mathrm{mL}$ of infusion.

\subsection{Evaluation of bioactive properties of hydromethanolic extracts and infusions}

2.5.1. In vitro antioxidant activity assays. Hydromethanolic extracts were redissolved in methanol/water $(80: 20 \mathrm{v} / \mathrm{v})$ to the final concentration of $20 \mathrm{mg} \mathrm{mL}^{-1}$, and infusions $\left(5 \mathrm{mg} \mathrm{mL}^{-1}\right)$ were further diluted to different concentrations to be subjected to the following assays. DPPH radical-scavenging activity (RSA) was evaluated by using an ELX800 microplate reader (Bio-Tek Instruments, Inc.; Winooski, VT, USA), and calculated as a percentage of DPPH discolouration using the formula: \% RSA = $\left[\left(A_{\mathrm{DPPH}}-A_{\mathrm{S}}\right) / A_{\mathrm{DPPH}}\right] \times 100$, where $A_{\mathrm{S}}$ is the absorbance of the solution containing the sample at $515 \mathrm{~nm}$, and $A_{\mathrm{DPPH}}$ is the absorbance of the DPPH solution. Reducing power was evaluated by the capacity to convert $\mathrm{Fe}^{3+}$ into $\mathrm{Fe}^{2+}$, measuring the absorbance at $690 \mathrm{~nm}$ in the microplate reader mentioned above. Inhibition of $\beta$-carotene bleaching was evaluated though the $\beta$-carotene/linoleate assay; the neutralization of linoleate free radicals avoids $\beta$-carotene bleaching, which is measured by the formula: ( $\beta$-carotene absorbance after $2 \mathrm{~h}$ of assay/initial absorbance) $\times 100$. Lipid peroxidation inhibition in porcine brain homogenates was evaluated by the decrease in thiobarbituric acid reactive substances (TBARS); the color intensity of the malondialdehyde-thiobarbituric acid (MDA-TBA) was measured by its absorbance at $532 \mathrm{~nm}$; the inhibition was calculated using the following formula: Inhibition ratio $(\%)=[(\mathrm{A}-\mathrm{B}) / \mathrm{A}] \times 100$, where $\mathrm{A}$ and $\mathrm{B}$ were the absorbance of the control and the sample solution, respectively. ${ }^{28}$ The final results were expressed in $\mathrm{EC}_{50}$ values $(\mathrm{mg}$ $\mathrm{mL}^{-1}$ ); sample concentration providing $50 \%$ of antioxidant activity or 0.5 of absorbance in the reducing power assay. Trolox was used as the positive control.

2.5.2. Cytotoxicity in tumor cell lines and in non-tumor primary cells. Hydromethanolic extracts (final concentration 
$8 \mathrm{mg} \mathrm{mL} \mathrm{m}^{-1}$, redissolved in water) and infusions $\left(5 \mathrm{mg} \mathrm{mL} \mathrm{m}^{-1}\right)$ were further diluted to different concentrations to be subjected to in vitro antitumor activity and hepatotoxicity evaluation.

The human tumor cell lines used were: HeLa (cervical carcinoma), HepG2 (hepatocellular carcinoma), MCF-7 (breast adenocarcinoma) and NCI-H460 (non-small cell lung cancer). Each of the cell lines were plated in a 96-well plate, at an appropriate density $\left(7.5 \times 10^{3}\right.$ cells per well for MCF-7 and NCI-H460 and $1.0 \times 10^{4}$ cells per well for HeLa and HepG2) and were allowed to attach for $24 \mathrm{~h}$. Afterwards, various extract concentrations were added to the cells and incubated for $48 \mathrm{~h}$. Afterwards, cold trichloroacetic acid (TCA 10\%, $100 \mu \mathrm{L}$ ) was used in order to bind the adherent cells and further incubated for $60 \mathrm{~min}$ at $4^{\circ} \mathrm{C}$. After the incubation period, the plates were washed with deionised water and dried and sulforhodamine $\mathrm{B}$ solution (SRB $0.1 \%$ in $1 \%$ acetic acid, $100 \mu \mathrm{L}$ ) was then added to each plate well and incubated for $30 \mathrm{~min}$ at room temperature. The plates were washed with acetic acid (1\%) in order to remove the unbound SRB and then air dried; the bound SRB was solubilised with Tris $(10 \mathrm{mM}, 200 \mu \mathrm{L})$ and the absorbance was measured at $540 \mathrm{~nm}$ using an ELX800 microplate reader (Bio-Tek Instruments, Inc.; Winooski, VT, USA). ${ }^{28}$ The results were expressed in $\mathrm{GI}_{50}$ values; the sample concentration that inhibited $50 \%$ of the net cell growth. Ellipticine was used as the positive control.

For hepatotoxicity evaluation, a freshly harvested porcine liver, obtained from a local slaughter house, was used in order to obtain the cell culture, designated as PLP2. The liver tissues were rinsed in Hank's balanced salt solution containing penicillin $\left(100 \mathrm{U} \mathrm{mL}^{-1}\right)$, streptomycin $\left(100 \mu \mathrm{g} \mathrm{mL} \mathrm{m}^{-1}\right)$ and divided into $1 \times 1 \mathrm{~mm}^{3}$ explants. A few of these explants were transferred to tissue flasks $\left(25 \mathrm{~cm}^{2}\right)$ containing DMEM supplemented with fetal bovine serum (FBS, 10\%), nonessential amino acids $(2 \mathrm{mM})$, penicillin $\left(100 \mathrm{U} \mathrm{mL}^{-1}\right)$ and streptomycin $\left(100 \mathrm{mg} \mathrm{mL}^{-1}\right.$ ) and incubated at $37{ }^{\circ} \mathrm{C}$ under a humidified atmosphere $\left(5 \% \mathrm{CO}_{2}\right)$. The medium was changed every two days and the cell cultivation was continuously monitored using a phase contrast microscope. When confluence was reached, the cells were sub-cultured and plated in a 96-well plate (density of $1.0 \times 10^{4}$ cells per well) containing DMEM supplemented with FBS (10\%), penicillin (100 $\mathrm{U} \mathrm{mL}^{-1}$ ) and streptomycin $\left(100 \mu \mathrm{g} \mathrm{mL}^{-1}\right)$. The growth inhibition was evaluated using the SRB assay, previously described. ${ }^{28}$ The results were expressed in $\mathrm{GI}_{50}$ values; the sample concentration that inhibited $50 \%$ of the net cell growth. Ellipticine was used as the positive control.

\subsection{Statistical analysis}

Three samples were used for each species and all the assays were carried out in triplicate. Results were expressed as mean values and standard deviation (SD) and analysis was performed through a Student's $t$-test with $\alpha=0.05$, using the SPSS v. 22.0 program.

\section{Results and discussion}

\subsection{Nutritional value and chemical characterization of C. officinalis and M. cervina dry material and infusions}

The results of the nutritional and estimated energy values obtained in the dry plants and infusions of C. officinalis and M. cervina are shown in Table 1 . Carbohydrates, calculated by difference for the dry plant, were the most abundant macronutrients and M. cervina showed the highest values, both in the infusions $(0.05 \mathrm{~g}$ per $100 \mathrm{~mL})$ and in dry material $(86 \mathrm{~g}$ per $100 \mathrm{~g} \mathrm{dw}$ ). Mentha cervina also revealed a higher protein content (6 g per $100 \mathrm{~g} \mathrm{dw}$ ), while C. officinalis showed higher ash and fat levels (14 g per $100 \mathrm{~g}$ dw and $6 \mathrm{~g}$ per $100 \mathrm{~g}$ dw, respectively). The infusion prepared using both plants did not reveal the presence of fat, ash and proteins, therefore the energy value was calculated taking into account total carbohydrates, calculated by the total free sugar content. The energy value calculated for the dry plants (376 kcal per $100 \mathrm{~g} \mathrm{dw}$, on average) did not show significant differences between C. officinalis and M. cervina $(p>0.05)$.

The composition of free sugars, organic acids and tocopherols of the dry plants and infusions is presented in Table 2. There is scarce information about $C$. officinalis, except regarding its use as a cosmetic ingredient ${ }^{6}$ and its composition in water-soluble polysaccharides, ${ }^{30}$ while no information about $M$. cervina was found. Five free sugars were identified in C. officinalis (xylose, fructose, glucose, sucrose and trehalose), while xylose could not be found in M. cervina. Calendula officinalis showed higher levels of fructose $(5 \mathrm{~g}$ per $100 \mathrm{~g}$ plant dw, $19 \mathrm{mg}$ per $100 \mathrm{~mL}$ infusion), sucrose (4 g per $100 \mathrm{~g}$ plant dw, $14 \mathrm{mg}$ per $100 \mathrm{~mL}$ infusion), and total free sugars

Table 1 Nutritional and energy values of plant dry material and infusions of $C$. officinalis and $M$. cervina

\begin{tabular}{|c|c|c|c|c|c|c|}
\hline & \multicolumn{3}{|l|}{ Dry material } & \multicolumn{3}{|l|}{ Infusions } \\
\hline & C. officinalis & M. cervina & $\begin{array}{l}\text { Student's } t \text {-test } \\
p \text {-value }\end{array}$ & C. officinalis & M. cervina & $\begin{array}{l}\text { Student's } t \text {-test } \\
p \text {-value }\end{array}$ \\
\hline Ash (g per $100 \mathrm{~g})$ & $14 \pm 1$ & $6.9 \pm 0.1$ & $<0.001$ & $\mathrm{np}$ & $\mathrm{np}$ & - \\
\hline Proteins (g per $100 \mathrm{~g}$ ) & $2.4 \pm 0.5$ & $5.9 \pm 0.2$ & $<0.001$ & - & - & - \\
\hline Fat $(\mathrm{g}$ per $100 \mathrm{~g})$ & $5.6 \pm 0.2$ & $1.4 \pm 0.1$ & $<0.001$ & - & - & - \\
\hline Carbohydrates (g per $100 \mathrm{~g}$ ) & $78 \pm 2$ & $85.8 \pm 0.2$ & $<0.001$ & $0.038 \pm 0.003^{a}$ & $0.048 \pm 0.003^{a}$ & 0.012 \\
\hline
\end{tabular}

$\mathrm{np}$ - not performed. ${ }^{a}$ Values are expressed per $100 \mathrm{~mL}$ of infusion. In each row, $p<0.05$ means significant differences. 
Table 2 Chemical composition in free sugars, organic acids and tocopherols of plant dry material and infusions of $C$. officinalis and $M$. cervina

\begin{tabular}{|c|c|c|c|c|c|c|c|c|}
\hline \multirow[b]{2}{*}{ Sugars } & \multicolumn{4}{|l|}{ Dry material } & \multicolumn{4}{|l|}{ Infusions } \\
\hline & $\begin{array}{l}\text { C. officinalis } \\
\text { (g per } 100 \mathrm{~g} \text { ) }\end{array}$ & $\begin{array}{l}\text { M. cervina } \\
\text { (g per } 100 \mathrm{~g} \text { ) }\end{array}$ & \multicolumn{2}{|l|}{ Student's $t$-test $p$-value } & $\begin{array}{l}\text { C. officinalis } \\
\text { (mg per } 100 \mathrm{~mL})\end{array}$ & $\begin{array}{l}\text { M. cervina } \\
(\mathrm{mg} \text { per } 100 \mathrm{~mL})\end{array}$ & \multicolumn{2}{|c|}{ Student's $t$-test $p$-value } \\
\hline Xylose & $1.70 \pm 0.02$ & nd & - & & nd & nd & - & \\
\hline Fructose & $4.7 \pm 0.3$ & $3.3 \pm 0.1$ & $<0.001$ & & $19 \pm 1$ & $12 \pm 1$ & $<0.001$ & \\
\hline Glucose & $0.8 \pm 0.1$ & $3.5 \pm 0.1$ & $<0.001$ & & $7 \pm 1$ & $16 \pm 1$ & $<0.001$ & \\
\hline Sucrose & $3.9 \pm 0.1$ & $2.13 \pm 0.04$ & $<0.001$ & & $14 \pm 1$ & $10 \pm 1$ & 0.022 & \\
\hline Organic acids & \multicolumn{2}{|c|}{ (mg per $100 \mathrm{~g}$ ) } & \multicolumn{2}{|l|}{ (mg per $100 \mathrm{~g}$ ) } & \multicolumn{2}{|c|}{ (mg per $100 \mathrm{~mL})$} & \multicolumn{2}{|c|}{ (mg per $100 \mathrm{~mL}$ ) } \\
\hline Oxalic acid & \multicolumn{2}{|c|}{$718 \pm 7$} & $275 \pm 2$ & $<0.001$ & \multicolumn{2}{|c|}{$0.35 \pm 0.01$} & $\operatorname{tr}$ & - \\
\hline Quinic acid & \multicolumn{2}{|c|}{$392 \pm 3$} & $54 \pm 2$ & $<0.001$ & \multicolumn{2}{|c|}{$\operatorname{tr}$} & $\operatorname{tr}$ & - \\
\hline Malic acid & \multicolumn{2}{|c|}{$743 \pm 15$} & $144 \pm 2$ & $<0.001$ & \multicolumn{2}{|l|}{$\operatorname{tr}$} & $\operatorname{tr}$ & - \\
\hline Citric acid & \multicolumn{2}{|c|}{$963 \pm 23$} & $226 \pm 7$ & $<0.001$ & \multicolumn{2}{|c|}{$2.64 \pm 0.05$} & $0.82 \pm 0.02$ & $<0.001$ \\
\hline$\alpha$-Tocopherol & 19.40 & .01 & $1.94 \pm 0.04$ & $<0.001$ & $0.881 \pm 0$ & 0.143 & 0.003 & $<0.001$ \\
\hline$\beta$-Tocopherol & 1.48 & .08 & nd & - & nd & nd & & - \\
\hline$\gamma$-Tocopherol & 2.45 & & nd & - & nd & nd & & - \\
\hline$\delta$-Tocopherol & nd & & $0.050 \pm 0.001$ & - & nd & nd & & - \\
\hline Sum & 23.33 & .01 & $1.99 \pm 0.04$ & $<0.001$ & $0.881 \pm 0$ & 0.143 & 0.003 & $<0.001$ \\
\hline
\end{tabular}

nd - not detected; $\mathrm{tr}$ - traces. In each row, $p<0.05$ means significant differences.

(12 g per $100 \mathrm{~g}$ plant dw, $49 \mathrm{mg}$ per $100 \mathrm{~mL}$ infusion), while M. cervina gave higher levels of glucose ( $4 \mathrm{~g}$ per $100 \mathrm{~g}$ plant dw, $16 \mathrm{mg}$ per $100 \mathrm{~mL}$ infusion). Regarding dry plants, no significant differences $(p>0.05)$ were found in the content of trehalose ( $0.6 \mathrm{~g}$ per $100 \mathrm{~g}$ plant dw on average), although this sugar was not detected in the infusion of $M$. cervina.

Oxalic, quinic, malic, citric and fumaric acids were identified in $C$. officinalis and $M$. cervina. The highest total content was found in C. officinalis (2830 mg per $100 \mathrm{~g}$ plant dw, $3.0 \mathrm{mg}$ per $100 \mathrm{~mL}$ infusion), and the most abundant one was citric acid (963 mg per $100 \mathrm{~g}$ plant dw, $2.6 \mathrm{mg}$ per $100 \mathrm{~mL}$ infusion). In the $C$. officinalis infusion, only oxalic, citric and fumaric acids were detected, while citric acid was the only organic acid identified in $M$. cervina, probably due to degradation of some of these compounds by heat during the preparation procedure.

Calendula officinalis presented three tocopherol isoforms ( $\alpha, \beta$ and $\gamma$-tocopherols), while $M$. cervina presented only two ( $\alpha$ and $\delta$-tocopherols). In infusions, only $\alpha$-tocopherol was detected, the low tocopherol concentration in infusion samples could also be due to the extraction procedure (water extraction), and not only due to thermal treatment during the extraction process. Calendula officinalis showed the highest concentration of tocopherols (23 $\mathrm{mg}$ per $100 \mathrm{~g}$ plant $\mathrm{dw}$, $0.9 \mathrm{mg}$ per $100 \mathrm{~mL}$ infusion) and $\alpha$-tocopherol was the major isoform (19 mg per $100 \mathrm{~g}$ marigold plant dw; $2 \mathrm{mg}$ per $100 \mathrm{~mL}$ Hart's pennyroyal plant).

The fatty acid (FA) composition of both dry plants is shown in Table 3. The obtained fatty acid profiles were significantly different. In C. officinalis, saturated fatty acids (SFA; 77\%), mainly palmitic acid (C16:0, 36\%) and myristic acid (C14:0,
$25 \%$ ), predominated over polyunsaturated fatty acids (PUFA; 21\%); while in $M$. cervina PUFA (56\%), mainly $\alpha$-linolenic acid (C18:3n3, 46\%), predominated over SFA (34\%).

\subsection{Analysis of phenolic compounds in C. officinalis and $M$. cervina hydromethanolic extracts and infusions}

The phenolic compounds found in C. officinalis and M. cervina infusions and hydromethanolic extracts are listed in Tables 4 and 5, and their HPLC profiles can be observed in Fig. 1. The studied samples presented completely different profiles; C. officinalis presented thirteen different compounds, mainly glycosylated flavonols, while $M$. cervina presented eleven compounds, mainly caffeoyl derivatives (caffeic acid dimers, trimers and tetramers). In the literature there are several studies regarding the phenolic composition of C. officinalis, ${ }^{22,31-36}$ while for $M$. cervina only one study was found. ${ }^{26}$ Nevertheless, the phenolic profile of the infusions, the most common form of consumption of this plant, are limited.

The C. officinalis (marigold) phenolic profile presented two phenolic acids (compounds $\mathbf{1}$ and 2) and eleven flavonol derivatives (compounds 3-13). 5-O-Caffeoylquinic acid (chlorogenic acid, compound 2), quercetin-3-O-rutinoside (rutin; compound 4), isorhamnetin-3-O-rutinoside (narcissin; compound 11) and isorhamnetin-3-O-glucoside (compound 12) were positively identified according to their retention times, mass and UV-vis characteristics by comparison with commercial standards. These compounds have been previously reported by other authors in different tissues ${ }^{32,33,35,36}$ and pollen of 
Table 3 Fatty acid composition in the dry material of $C$. officinalis and M. cervina

\begin{tabular}{lrrl}
\hline & $\begin{array}{l}\text { Calendula } \\
\text { officinalis }\end{array}$ & \multicolumn{1}{l}{$\begin{array}{l}\text { Mentha } \\
\text { cervina }\end{array}$} & $\begin{array}{l}\text { Student's } t \text {-test } \\
\text { p-value }\end{array}$ \\
\hline C4:0 & $1.43 \pm 0.08$ & \multicolumn{1}{l}{-} & - \\
C6:0 & $0.51 \pm 0.03$ & $0.37 \pm 0.01$ & $<0.001$ \\
C8:0 & $0.66 \pm 0.02$ & $0.27 \pm 0.01$ & $<0.001$ \\
C10:0 & $0.28 \pm 0.01$ & $0.11 \pm 0.01$ & $<0.001$ \\
C12:0 & $3.66 \pm 0.09$ & $0.31 \pm 0.01$ & $<0.001$ \\
C13:0 & $0.050 \pm 0.001$ & $1.85 \pm 0.02$ & $<0.001$ \\
C14:0 & $24.93 \pm 0.27$ & $1.22 \pm 0.16$ & $<0.001$ \\
C14:1 & $0.10 \pm 0.01$ & - & - \\
C15:0 & $0.46 \pm 0.01$ & - & - \\
C16:0 & $35.57 \pm 0.11$ & $20.95 \pm 0.48$ & $<0.001$ \\
C16:1 & $0.21 \pm 0.03$ & $1.06 \pm 0.02$ & $<0.001$ \\
C17:0 & $0.47 \pm 0.02$ & $0.66 \pm 0.07$ & 0.003 \\
C18:0 & $5.93 \pm 0.18$ & $4.01 \pm 0.34$ & $<0.001$ \\
C18:1n9 & $2.47 \pm 0.01$ & $8.04 \pm 0.80$ & $<0.001$ \\
C18:2n6 & $9.32 \pm 0.02$ & $10.45 \pm 0.23$ & $<0.001$ \\
C18:3n3 & $11.08 \pm 0.10$ & $45.65 \pm 0.50$ & $<0.001$ \\
C20:0 & $0.80 \pm 0.01$ & $1.95 \pm 0.07$ & $<0.001$ \\
C20:1 & $0.12 \pm 0.01$ & - & - \\
C20:3n3+C21:0 & $0.77 \pm 0.02$ & $0.31 \pm 0.06$ & $<0.001$ \\
C22:0 & $0.33 \pm 0.02$ & $1.30 \pm 0.02$ & $<0.001$ \\
C22:1n9 & - & $0.40 \pm 0.02$ & - \\
C23:0 & - & $0.19 \pm 0.02$ & - \\
C24:0 & $0.88 \pm 0.02$ & $0.89 \pm 0.02$ & 0.261 \\
SFA (percentage) & $76.70 \pm 0.16$ & $34.08 \pm 0.98$ & $<0.001$ \\
MUFA (percentage) & $2.78 \pm 0.05$ & $9.51 \pm 0.56$ & $<0.001$ \\
PUFA (percentage) & $20.51 \pm 0.13$ & $56.42 \pm 0.21$ & $<0.001$ \\
& & & \\
& & &
\end{tabular}

The results of fatty acids are expressed in relative percentage. In each row, $p<0.05$ means significant differences. Butyric acid (C4:0); caproic acid (C6:0); caprylic acid (C8:0); capric acid (C10:0); lauric acid (C12:0); tridecanoic acid (C13:0); myristic acid (C14:0); myristoleic acid (C14:1); pentadecanoic acid (C15:0); palmitic acid (C16:0); palmitoleic acid (C16:1); heptadecanoic acid (C17:0); stearic acid (C18:0); oleic acid (C18:1n9c); linoleic acid (C18:2n6c); $\alpha$-linolenic acid (C18:3n3); arachidic acid (C20:0); eicosenoic acid (C20:1); cis-11,14,17eicosatrienoic acid and heneicosanoic acid (C20:3n + C21:0); behenic acid (C22:0); lignoceric acid (C24:0). SFA - saturated fatty acids; MUFA - monounsaturated fatty acids; PUFA - polyunsaturated fatty acids.

C. officinalis, ${ }^{34}$ as well as in marigold tinctures ${ }^{31}$ and infusions and decoctions. ${ }^{22}$

Compound $1\left([\mathrm{M}-\mathrm{H}]^{-}\right.$at $m / z$ 341) was identified as a caffeic acid hexoside. The remaining phenolic compounds corresponded to flavonol derivatives, derived from quercetin $\left(\lambda_{\max }\right.$ around $350 \mathrm{~nm}$ and $\mathrm{MS}^{2}$ fragment at $\mathrm{m} / \mathrm{z}$ 301), kaempferol ( $\lambda_{\max }$ around $348 \mathrm{~nm}, \mathrm{MS}^{2}$ fragment at $\mathrm{m} / \mathrm{z} 285$ ) and isorhamnetin $\left(\lambda_{\max }\right.$ at $354 \mathrm{~nm}, \mathrm{MS}^{2}$ fragment at $\mathrm{m} / z$ 315). Compounds $3\left([\mathrm{M}-\mathrm{H}]^{-}\right.$at $m / z$ 755), $5\left([\mathrm{M}-\mathrm{H}]^{-}\right.$at $m / z$ 739) and $6\left([\mathrm{M}-\mathrm{H}]^{-}\right.$at $\left.m / z 769\right)$, should respectively correspond to quercetin, kaempferol and isorhamnetin derivatives bearing two deoxyhexosyl and one hexosyl residues. The fact that only one $\mathrm{MS}^{2}$ fragment was released corresponding to the aglycone would suggest that the three sugars constitute a trisaccharide. Compounds similar to 3 and $\mathbf{6}$ have been previously described in marigold tissues ${ }^{32,33,35}$ and herbal preparations, ${ }^{22,31}$ and identified respectively as quercetin $3-O-2^{\mathrm{G}}$-rhamnosylrutinoside (manghaslin) and isorhamnetin $3-O-2^{\mathrm{G}}$-rhamnosylrutinoside (typhaneoside). ${ }^{37}$ Compound $\mathbf{5}$ corresponds to the equivalent kaempferol derivative that, as far as we know, has not been reported previously in marigold.

Compound 7 presented a pseudomolecular ion $[\mathrm{M}-\mathrm{H}]^{-}$at $m / z 595$, releasing an $\mathrm{MS}^{2}$ fragment at $m / z 301$ ([M - H-132$162]^{-}$, loss of pentosyl and hexosyl moieties), which allowed its tentative identification as quercetin- $O$-pentosylhexoside. Compound $8\left([\mathrm{M}-\mathrm{H}]^{-}\right.$at $\left.m / z 651\right)$ was $42 \mathrm{u}$ (acetyl residue) higher than compound 4 (rutin); nevertheless, since the actual nature of the glycosyl residue could not be confirmed, it was just assigned as quercetin- $O$-acetyldeoxyhexosylhexoside. Peak 9 $\left([\mathrm{M}-\mathrm{H}]^{-}\right.$at $m / z$ 623) showed identical UV and mass characteristics to compound $\mathbf{1 1}$ (isorhamnetin 3-O-rutinoside) but eluted a bit earlier. A similar compound was reported by Olennikov and Kashchenko ${ }^{35,36}$ and Ukiya et al. $^{7}$ in marigold flowers and identified as isorhamnetin-3-O-neohesperidoside (calendoflavoside), so that this identity was assumed for the compound detected herein. Compounds 10 and 13 presented pseudomolecular ions $[\mathrm{M}-\mathrm{H}]^{-}$at $m / z 505$ and 519 releasing $\mathrm{MS}^{2}$ fragments at $\mathrm{m} / \mathrm{z} 301$ (quercetin) and at $\mathrm{m} / \mathrm{z} 315$ (isorhamnetin), respectively, indicating the loss of an acetylhexoside residue $\left([\mathrm{M}-\mathrm{H}-42-162]^{-}\right)$. Similar compounds were also identified in marigold by Olennikov and Kashchenko ${ }^{35,36}$ as quercetin-3-O-(6"-acetyl)-glucoside and isorhamnetin-3-O-(6"acetyl)-glucoside, respectively; the latter one was also found in infusions and decoctions of marigold. ${ }^{22}$ These identities were also assumed for the compounds detected in our samples.

Isorhamnetin-3-O-rhamnosylrutinoside (typhaneoside; peak 6) and isorhamnetin-3-O-rutinoside (narcissin, peak 11) were the most abundant phenolics in the analyzed extracts and infusions of marigold (Table 5). These compounds were also reported as the main phenolic compounds in C. officinalis flowers. ${ }^{35}$

As mentioned above, the phenolic composition of M. cervina was characterised by the presence of caffeoyl derivatives, namely caffeic acid dimers, trimers and tetramers, compounds which have not been reported before in this species. To the best of our knowledge, the only study that reports on the phenolic composition of $M$. cervina was published by Politi et al., ${ }^{26}$ who identified four phenolic acids (protocatechuic acid, $p$-coumaric acid, caffeic acid and chlorogenic acid) and three flavonoids (epicatechin, orientin and rutin). The only common compound between the ones reported in that study and those detected herein was caffeic acid (compound $2^{\prime}$ ). This latter and trans-rosmarinic acid (compound $\mathbf{9}^{\prime}$ ) were positively identified according to their retention times, mass and UV-vis characteristics by comparison with commercial standards. Compound $\mathbf{5}^{\prime}\left([\mathrm{M}-\mathrm{H}]^{-}\right.$at $\left.m / z 521\right)$ yielded a fragment at $m / z$ 359 (rosmarinic acid) from the loss of $162 \mathrm{mu}$ (hexoside moiety), as well as other fragments identical to those observed for compound $\mathbf{9}^{\prime}$, which allowed its tentative identification as rosmarinic acid hexoside. Furthermore, compound $\mathbf{8}^{\prime}$ with similar characteristics to compound $\mathbf{9}^{\prime}$ should correspond to a rosmarinic acid isomer that was tentatively identified as cis-rosmarinic acid.

Compound $\mathbf{1}^{\prime}\left([\mathrm{M}-\mathrm{H}]^{-}\right.$at $m / z$ 433) was assigned as a caffeic acid derivative based on the characteristic fragment 
Table 4 Retention time (Rt), wavelengths of maximum absorption in the visible region $\left(\lambda_{\text {max }}\right)$, mass spectral data and identification of phenolic compounds in C. officinalis and $M$. cervina hydromethanolic extracts and infusions

\begin{tabular}{|c|c|c|c|c|c|}
\hline Compound & $\begin{array}{l}\mathrm{Rt} \\
(\mathrm{min})\end{array}$ & $\begin{array}{l}\lambda_{\max } \\
(\mathrm{nm})\end{array}$ & $\begin{array}{l}\text { Molecular ion } \\
{[\mathrm{M}-\mathrm{H}]^{-}(\mathrm{m} / \mathrm{z})}\end{array}$ & $\operatorname{MS}^{2}(m / z)$ & Tentative identification \\
\hline \multicolumn{6}{|l|}{ C. officinalis } \\
\hline 2 & 7.6 & 328 & 353 & 191(100), 179(8), 173(6), 161(11), 135(3) & 5-O-Caffeoylquinic acid \\
\hline 3 & 15.1 & 350 & 755 & $301(100)$ & Quercetin-3-O-rhamnosylrutinoside \\
\hline 4 & 16.7 & 354 & 609 & $301(100)$ & Quercetin-3-O-rutinoside \\
\hline 5 & 17.1 & 348 & 739 & $285(100)$ & Kaempferol-O-rhamnosylrutinoside \\
\hline 7 & 18.3 & 350 & 595 & $301(100)$ & Quercetin-O-pentosylhexoside \\
\hline 8 & 18.5 & 350 & 651 & $609(5), 301(50)$ & $\begin{array}{l}\text { Quercetin-O- } \\
\text { acetyldeoxyhexosylhexoside }\end{array}$ \\
\hline 9 & 19.6 & 356 & 623 & 315(100), 300(18) & Isorhamnetin-3-O-neohesperidoside \\
\hline 10 & 21.2 & 356 & 505 & $301(65)$ & Quercetin-3-O-(6"-acetyl)-glucoside \\
\hline 11 & 22.7 & 356 & 623 & 315(100), 300(10) & Isorhamnetin-3-O-rutinoside \\
\hline 12 & 24.2 & 354 & 477 & $315(100), 300(15)$ & Isorhamnetin-3-O-glucoside \\
\hline $2^{\prime}$ & 10.7 & 324 & 179 & $135(100)$ & Caffeic acid \\
\hline $3^{\prime}$ & 15.4 & 326 & 537 & $\begin{array}{l}\text { 493(59), 339(100), 313(21), 295(37), } \\
\text { 269(14), 229(8), 197(33), 179(22), 135(24) }\end{array}$ & Lithospermic acid A isomer \\
\hline $4^{\prime}$ & 16.6 & $272,324 \mathrm{sh}$ & 539 & $\begin{array}{l}\text { 495(13), 359(21), 297(100), 279(64), 197(34), } \\
179(36), 161(34), 135(18)\end{array}$ & Yunnaneic acid D isomer \\
\hline $5^{\prime}$ & 18.2 & 322 & 521 & $359(100), 197(21), 179(34), 161(73), 135(15)$ & Rosmarinic acid hexoside \\
\hline $6^{\prime}$ & 18.5 & $274,324 \mathrm{sh}$ & 539 & $\begin{array}{l}\text { 495(44), 359(28), 297(100), 279(11), } 197(33), \\
179(31), 161(84), 135(16)\end{array}$ & Yunnaneic acid D isomer \\
\hline $7^{\prime}$ & 20.0 & 276 & 719 & $539(12), 521(10), 359(65), 197(6), 179(8), 161(17), 135(3)$ & Sagerinic acid \\
\hline $8^{\prime}$ & 22.4 & 328 & 359 & $197(22), 179(27), 161(100), 135(14)$ & cis-Rosmarinic acid isomer \\
\hline $9^{\prime}$ & 23.3 & 328 & 359 & $197(30), 179(54), 161(100), 135(7)$ & trans-Rosmarinic acid \\
\hline $10^{\prime}$ & 26.7 & 326 & 493 & $\begin{array}{l}359(85), 313(9), 295(71), 269(8), 197(33), 179(44), \\
161(100), 135(90)\end{array}$ & Isosalvianolic acid A \\
\hline $\mathbf{1 1}^{\prime}$ & 31.6 & 324 & 493 & $\begin{array}{l}359(84), 313(13), 295(58), 269(7), 197(31), 179(41) \\
161(91), 135(86)\end{array}$ & Salvianolic acid A \\
\hline
\end{tabular}

ions at $m / z 179$ [caffeic acid-H] $]^{-}$and 135 [caffeic acid- $\left.\mathrm{CO}_{2}-\mathrm{H}\right]^{-}$. Nevertheless, no definite structure could be matched to the molecular mass of the compound that remains as an unidentified caffeic acid derivative. Compound $3^{\prime}$ presented a pseudomolecular ion $[\mathrm{M}-\mathrm{H}]^{-}$at $m / z 537$, the UV spectrum and fragmentation pattern being consistent with the caffeic acid trimer lithospermic acid A. This compound can easily lose the 8 "-carboxyl group $(-44 \mathrm{u})$ releasing a fragment at $\mathrm{m} / \mathrm{z}$ 493 that further breaks down to form the fragment ions at $\mathrm{m} / \mathrm{z}$ 313 and 295. However, peak 3' showed a different retention time compared to lithospermic acid A, which is expected to elute later than trans-rosmarinic acid, as previously observed in other Lamiaceae analyzed in our laboratory. ${ }^{29,38}$ Other compounds with the same molecular weight are salvianolic acids $\mathrm{H}$ or I, although they showed different fragmentation patterns. ${ }^{39,40}$ A compound with similar characteristics was found in a sample of Melissa officinalis and identified as a lithospermic acid A isomer, ${ }^{29}$ an identity that has been tentatively assumed for peak $\mathbf{3}^{\prime}$ detected herein.

Compounds $\mathbf{4}^{\prime}$ and $\mathbf{6}^{\prime}\left([\mathrm{M}-\mathrm{H}]^{-}\right.$at $m / z$ 539) presented the same pseudomolecular ion and similar fragmentation pattern and UV spectra, coherent with those of yunnaneic acid D as described by Chen et al. ${ }^{39}$ in Salvia miltiorrhiza, based on which they were identified as yunnaneic acid D isomers. Compound $7^{\prime}$ showed a pseudomolecular ion $[\mathrm{M}-\mathrm{H}]^{-}$at $\mathrm{m} / z 719$ and an $\mathrm{MS}^{2}$ majority fragment at $\mathrm{m} / \mathrm{z} 359$ corresponding to $[\mathrm{M}-2 \mathrm{H}]^{2-}$; these mass characteristics coincided with those of sagerinic acid, a rosmarinic acid dimer, reported by us in other plant samples. ${ }^{29,38}$ Finally, compounds $\mathbf{1 0}^{\prime}$ and $\mathbf{1 1}^{\prime}$ also presented the same pseudomolecular ion $[\mathrm{M}-\mathrm{H}]^{-}$at $m / z 493$, which together with the characteristic fragment ions at $\mathrm{m} / \mathrm{z}$ 313, 295 and 197 and UV spectra allowed assigning them as salvianolic acid A isomers, e.g., isosalvianolic acid A and salvianolic acid A, as previously described by Ruan et al. ${ }^{40}$

Rosmarinic acid was the most abundant phenolic compound in M. cervina. This compound had not been identified in the only report previously published on the phenolic composition of this species, ${ }^{26}$ which described a completely different phenolic profile.

\subsection{Bioactivity of $C$. officinalis and $M$. cervina hydromethanolic extracts and infusions}

The in vitro antioxidant and cytotoxic properties of $C$. officinalis and $M$. cervina, hydromethanolic extracts and infusions were evaluated, and the results are given in Table 6. 
Table 5 Quantification of phenolic compounds in C. officinalis and M. cervina infusions ( $\mu \mathrm{g}$ per $100 \mathrm{~mL}$ ) and hydromethanolic extracts (mg per $100 \mathrm{~g}$ extract)

Calendula officinalis

Compounds

Caffeic acid hexoside

5-O-Caffeoylquinic acid

Quercetin-3-O-rhamnosylrutinoside

Quercetin-3-O-rutinoside

Kaempferol-O-rhamnosylrutinoside

Isorhamnetin-3-O-rhamnosylrutinoside

Quercetin- $O$-pentosylhexoside

Quercetin- $O$-acetyldeoxyhexosylhexoside

Isorhamnetin-3-O-neohesperidoside

Quercetin-3-O-(6"-acetyl)-glucoside

Isorhamnetin-3-O-rutinoside

Isorhamnetin-3-O-glucoside

Isorhamnetin-3-O-(6"-acetyl)-glucoside

Total phenolic acids

Total flavonoids

Total phenolic compounds

nd - not detected.
Mentha cervina

Hydromethanolic

Infusion extract

Compounds

Hydromethanolic

extract

$149 \pm 3 \quad 33.32 \pm 0.01$

$134 \pm 3 \quad 28.58 \pm 0.04$

$95+3 \quad 22+1$

$59 \pm 6 \quad 10.0 \pm 0.4$

$1547 \pm 9 \quad 305 \pm 8$

$34 \pm 1 \quad 8.0 \pm 0.1$

$23 \pm 2 \quad 3.8 \pm 0.1$

$316 \pm 8 \quad 66.5 \pm 0.4$

$102+5 \quad 20 \pm 1$

$1408 \pm 11 \quad 288 \pm 1$

$111 \pm 3 \quad 18 \pm 1$

$334 \pm 4 \quad 51 \pm 2$

$190 \pm 2 \quad 39.73 \pm 0.02$

$4161 \pm 19 \quad 821 \pm 9$

$4351 \pm 19 \quad 861 \pm 9$
Caffeic acid derivative

Caffeic acid

Lithospermic acid A isomer

Yunnaneic acid D isomer

Rosmarinic acid hexoside

Yunnaneic acid D isomer

Sagerinic acid

cis-Rosmarinic acid

trans-Rosmarinic acid

Isosalvianolic acid A

Salvianolic acid A

$\begin{array}{cc}104 \pm 2 & 16.1 \pm 0.2 \\ 96 \pm 1 & 23 \pm 2 \\ 162 \pm 16 & 10 \pm 1 \\ 262 \pm 8 & 31 \pm 3 \\ 195 \pm 1 & 30 \pm 5 \\ 295 \pm 15 & 30.2 \pm 0.4 \\ 333 \pm 7 & 42 \pm 1 \\ 441 \pm 25 & 68 \pm 4 \\ 3224 \pm 88 & 754 \pm 2 \\ 31 \pm 2 & 27 \pm 1 \\ 234 \pm 23 & 23 \pm 1 \\ & \\ & \\ 5376 \pm 88 & 1053 \pm 13 \\ \text { nd } & \text { nd } \\ 5376 \pm 88 & 1053 \pm 13\end{array}$

A

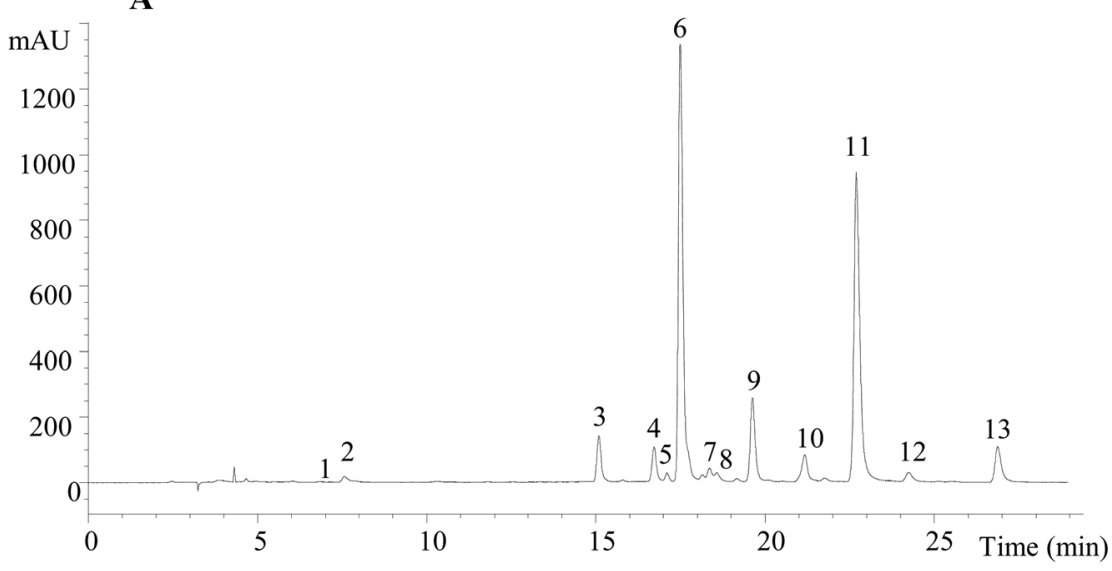

B

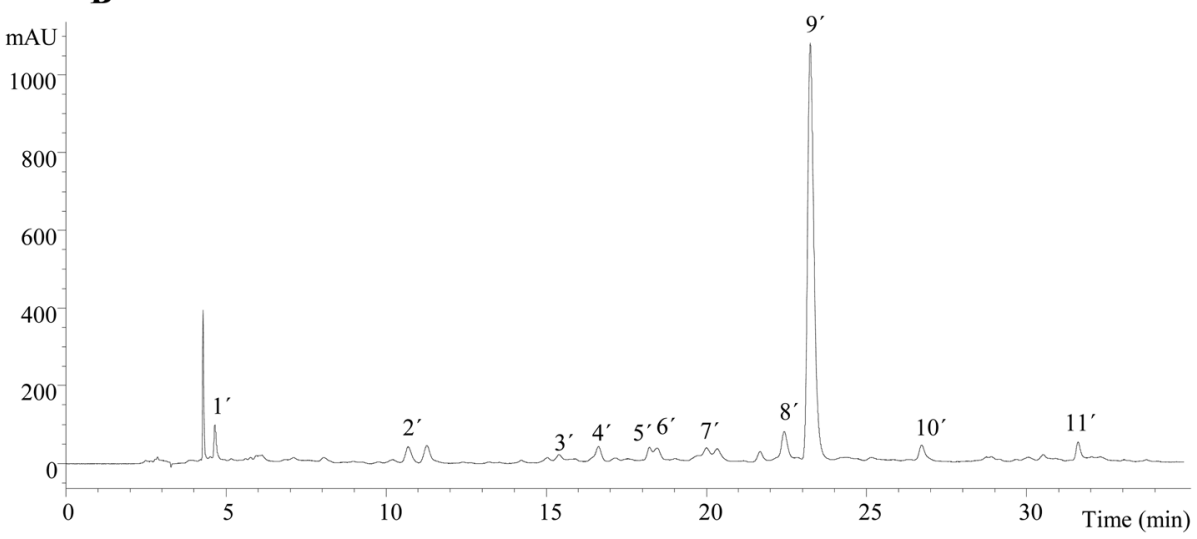

Fig. 1 Phenolic profile of $C$. officinalis (A) and M. cervina (B) recorded at 370 and $280 \mathrm{~nm}$, respectively. 
Table 6 Bioactive properties of hydromethanolic extracts and infusions of C. officinalis and M. cervina

\begin{tabular}{|c|c|c|c|c|c|c|}
\hline & \multicolumn{3}{|c|}{ Hydromethanolic extracts } & \multicolumn{3}{|l|}{ Infusions } \\
\hline & C. officinalis & M. cervina & $\begin{array}{l}\text { Student's } t \text {-test } \\
p \text {-value }\end{array}$ & C. officinalis & M. cervina & $\begin{array}{l}\text { Student's } t \text {-test } \\
p \text {-value }\end{array}$ \\
\hline \multicolumn{7}{|l|}{ Antioxidant activity $\left(\mathrm{EC}_{50} \mathrm{mg} \mathrm{mL}^{-1}\right)$} \\
\hline DPPH scavenging activity & $4.6 \pm 0.1$ & $0.21 \pm 0.01$ & $<0.001$ & $6.5 \pm 0.1$ & $0.81 \pm 0.02$ & $<0.001$ \\
\hline Reducing power & $0.82 \pm 0.03$ & $0.14 \pm 0.01$ & $<0.001$ & $2.61 \pm 0.04$ & $0.24 \pm 0.01$ & $<0.001$ \\
\hline$\beta$-Carotene bleaching inhibition & $2.17 \pm 0.02$ & $1.12 \pm 0.01$ & $<0.001$ & $0.91 \pm 0.04$ & $1.24 \pm 0.01$ & $<0.001$ \\
\hline TBARS inhibition & $1.21 \pm 0.01$ & $0.070 \pm 0.001$ & $<0.001$ & $2.9 \pm 0.1$ & $0.06 \pm 0.01$ & $<0.001$ \\
\hline \multicolumn{7}{|l|}{ Antitumor activity $\left(\mathrm{GI}_{50}\right.$ values $\mu \mathrm{g} \mathrm{mL}^{-1}$ ) } \\
\hline MCF-7 (breast carcinoma) & $>400$ & $294 \pm 2$ & - & $>250$ & $>250$ & - \\
\hline NCI-H460 (non-small cell lung cancer) & $>400$ & $320 \pm 4$ & - & $>250$ & $>250$ & - \\
\hline HeLa (cervical carcinoma) & $256 \pm 4$ & $223 \pm 4$ & $<0.001$ & $>250$ & $>250$ & - \\
\hline HepG2 (hepatocellular carcinoma) & $330 \pm 8$ & $339 \pm 9$ & $<0.001$ & $>250$ & $>250$ & - \\
\hline \multicolumn{7}{|l|}{ Hepatotoxicity $\left(\mathrm{GI}_{50}\right.$ values $\mu \mathrm{g} \mathrm{mL}^{-1}$ ) } \\
\hline PLP2 & $>400$ & $>400$ & - & $>250$ & $>250$ & - \\
\hline
\end{tabular}

The highest antioxidant activity was observed for M. cervina; its hydromethanolic extract showed the lowest $\mathrm{EC}_{50}$ values in all the assays, except in the $\beta$-carotene bleaching inhibition, where $C$. officinalis infusion gave higher antioxidant activity. These differences could be related with the different phenolic profiles of each plant (Table 5). Whereas M. cervina showed phenolic acid derivatives as the major compounds, C. officinalis proved to have flavonoids as the main phenolic molecules. The in vitro as also the in vivo antioxidant activity of $C$. officinalis has been previously reported. ${ }^{4,18-20}$ The results of the extracts studied revealed a DPPH radical scavenging activity lower than that of aqueous extracts and hydromethanolic extracts obtained by Ćetković et al. ${ }^{19}{ }_{\left(\mathrm{EC}_{50}\right.}: 0.30-0.90 \mathrm{mg}$ $\mathrm{mL}^{-1}$ ). All the publications confirmed the antioxidant capacity of $C$. officinalis, suggesting that many of its therapeutic activities are due to that capacity.

Regarding antitumor potential, the most promising results were obtained for the $M$. cervina hydromethanolic extract, which exhibited cytotoxicity against the four tested tumor cell lines, being more active against cervical carcinoma $\left(\mathrm{HeLa}, \mathrm{GI}_{50}=\right.$ $223 \mu \mathrm{g} \mathrm{mL} \mathrm{m}^{-1}$ ). The hydromethanolic extract of C. officinalis revealed selectivity against cervical $\left(\mathrm{HeLa}, \mathrm{GI}_{50}=256 \mu \mathrm{g} \mathrm{mL} \mathrm{m}^{-1}\right.$ ) and hepatocellular (HepG2, $\mathrm{GI}_{50}=330 \mu \mathrm{g} \mathrm{mL} \mathrm{m}^{-1}$ ) carcinoma. The infusions of both plants did not show effects on the tumor cell lines, however, and none of the extracts revealed toxicity against non-tumor cells (PLP2). In contrast to the lack of studies with $M$. cervina in this regard, there are some reports that evaluate the antitumor activity of $C$. officinalis extracts and isolated compounds by using in vitro and in vivo models. $^{7,21,22}$ The antitumor activity of triterpene glycosides isolated from marigold was shown by Ukiya et al., ${ }^{7}$ and the results obtained by Matic et $a l^{22}$ on marigold infusion against
$\operatorname{HeLa}\left(\mathrm{GI}_{50}=750 \mu \mathrm{g} \mathrm{mL} \mathrm{m}^{-1}\right)$ and other tumor cell lines, are consistent with the present study.

In summary, C. officinalis (marigold flowers) and M. cervina (Hart's pennyroyal leaves) contain phytochemicals that are of great interest due to their potential antioxidant and antitumor activities. Overall, the present study extends the knowledge of C. officinalis and provides innovative results for $M$. cervina regarding chemical characterization and bioactive properties, contributing to extend their use as functional ingredients, and for medical purposes.

\section{Acknowledgements}

The authors are grateful to the Foundation for Science and Technology (FTC, Portugal) for financial support to CIMO (Pest-OE/AGR/UI0690/2014), R. C. Calhelha (SFRH/BPD/68344/ 2010) and L. Barros (SFRH/BPD/107855/2015) grants.

\section{References}

1 A. Gurib-Fakim, Mol. Aspects Med., 2006, 27, 1-93.

2 WHO, Estrategia de la OMS sobre medicina tradicional 2014-2023, 2013.

3 E. Efstratiou, A. I. Hussain, P. S. Nigam, J. E. Moore, M. A. Ayub and J. R. Rao, Complementary Ther. Clin. Pract., 2012, 18, 173-176.

4 M. A. Hamzawy, E. S. M. El-denshary, N. S. Hassan, F. A. Mannaa and M. A. Abdel-wahhab, ISRN Nutr., 2013, 9.

5 WHO, Flos calendulae, In WHO monographs on selected medicinal plants, Ginebra, 2002, vol. 2, pp. 35-44. 
6 F. A. Andersen, W. F. Bergfeld, D. V. Belsito, R. Hill, C. D. Klaassen, D. C. Liebler, J. G. Marks, R. C. Shank, T. J. Slaga and P. W. Snyder, Int. J. Toxicol., 2010, 29, 221S243S.

7 M. Ukiya, T. Akihisa, K. Yasukawa, H. Tokuda, T. Suzuki and Y. Kimura, J. Nat. Prod., 2006, 69, 1692-1696.

8 N. Tanideh, P. Tavakoli, M. A. Saghiri, F. Garcia-Godoy, D. Amanat, A. A. Tadbir, S. M. Samani and A. Tamadon, Oral Surg. Oral Med. Oral Pathol. Oral Radiol., 2013, 115, 332-338.

9 N. Babaee, D. Moslemi, M. Khalilpour, F. Vejdani, Y. Moghadamnia, A. Bijani, M. Baradaran, M. T. Kazemi, A. Khalilpour, M. Pouramir and A. A. Moghadamnia, Daru, J. Pharm. Sci., 2013, 21, 18.

10 Z. Kalvatchev, R. Walder and D. Garzaro, Biomed. Pharmacother., 1997, 51, 176-180.

11 Z. Amirghofran, M. Azadbakht and M. H. Karimi, J. Ethnopharmacol., 2000, 72, 167-172.

12 M. Yoshikawa, T. Murakami, A. Kishi, T. Kageura and H. Matsuda, Chem. Pharm. Bull., 2001, 49, 863-870.

13 S. Bashir, K. H. Janbaz, Q. Jabeen and A. H. Gilani, Phytother. Res., 2006, 20, 906-910.

14 M. Alexenizer and A. Dorn, J. Pestic. Sci., 2007, 80, 205-215.

15 S. Pérez-Gutiérrez, R. Vargas-Solís, M. Zavala S, C. Pérez-G and R. M. Pérez-G, Phytother. Res., 1998, 12, S49-S50.

16 D. Ray, S. Mukherjee, M. Falchi, A. Bertelli and D. K. Das, Curr. Pharm. Biotechnol., 2010, 11, 849-854.

17 L. M. Barajas-Farias, J. I. Pérez-Carreón, E. Arce-Popoca, S. Fattel-Fazenda, L. Alemán-Lazarini, S. Hernández-García, M. Salcido-Neyoy, F. G. Cruz-Jiménez, J. Camacho and S. Villa-Treviño, Planta Med., 2006, 72, 217-221.

18 C. A. S. Cordova, I. R. Siqueira, C. A. Netto, R. A. Yunes, A. M. Volpato, V. Cechinel Filho, R. Curi-Pedrosa and T. B. Creczynski-Pasa, Redox Rep., 2002, 7, 95-102.

19 G. S. Ćetković, S. M. Djilas, J. M. Čanadanović-Brunet and V. T. Tumbas, Food Res. Int., 2004, 37, 643-650.

20 K. C. Preethi, G. Kuttan and R. Kuttan, Pharm. Biol., 2006, 44, 691-697.

21 G. Matysik, M. Wójciak-Kosior and R. Paduch, J. Pharm. Biomed. Anal., 2005, 38, 285-292.

22 I. Z. Matić, Z. Juranić, K. Savikin, G. Zdunić, N. Nađvinski and D. Gođevac, Phytother. Res., 2013, 27, 852-858.
23 R. Morales, in Flora Ibérica, Madrid, Real Jardín Botánico, 2010, pp. 336-347.

24 O. Póvoa, G. Ribeiro, L. Rodrigues, P. Lobato, P. Monteiro, A. Monteiro and M. Martins-Moldão, in Acta Horticulturae, 2009, vol. 826, pp. 193-200.

25 L. Rodrigues, A. Duarte, A. C. Figueiredo, L. Brito, G. Teixeira, M. Moldão and A. Monteiro, Med. Chem. Res., 2012, 21, 3485-3490.

26 M. Politi, C. L. Rodrigues, M. S. Gião, M. E. Pintado and P. M. L. Castro, Nat. Prod. Commun., 2008, 3, 2065-2068.

27 W. Horwitz and G. Latimer, in $A O A C$, AOAC International, Gaithersburg, MD, 18th edn, 2005.

28 L. Barros, E. Pereira, R. C. Calhelha, M. Dueñas, A. M. Carvalho, C. Santos-Buelga and I. C. F. R. Ferreira, J. Funct. Foods, 2013, 5, 1732-1740.

29 L. Barros, M. Dueñas, M. I. Dias, M. J. Sousa, C. SantosBuelga and I. C. F. R. Ferreira, Food Chem., 2013, 136, 1-8.

30 A. P. Korzh, A. M. Gur, M. V. Belousov, M. S. Yusubov and M. L. Belyanin, Pharm. Chem. J., 2012, 46, 219-221.

31 A. R. Bilia, D. Salvini, G. Mazzi and F. F. Vincieri, Chromatographia, 2001, 53, 210-215.

32 I. Mašterová, Z. Grančaiová, S. Uhrínová, V. Suchý, C. K. Ubik and M. Nagy, Chem. Pap., 1991, 45, 105-108.

33 V. A. Kurkin and O. V. Sharova, Chem. Nat. Compd., 2007, 43, 216-217.

34 D. N. Olennikov and N. I. Kashchenko, Chem. Nat. Compd., 2014, 50, 589-593.

35 D. N. Olennikov and N. I. Kashchenko, Chem. Nat. Compd., 2013, 49, 833-840.

36 D. N. Olennikov and N. I. Kashchenko, Chem. Nat. Compd., 2014, 50, 633-637.

37 E. Vidal-Ollivier, R. Elias, F. Faure, A. Babadjamian, F. Crespin, G. Balansard and G. Boudon, Planta Med., 1989, $55,73-74$.

38 N. Martins, L. Barros, C. Santos-Buelga, M. Henriques, S. Silva and I. C. F. R. Ferreira, Food Chem., 2015, 170, 378385.

39 H. Chen, Q. Zhang, X. M. Wang, J. Yang and Q. Wang, Phytochem. Anal., 2011, 22, 247-257.

40 M. Ruan, Y. Li, X. Li, J. Luo and L. Kong, J. Pharm. Biomed. Anal., 2012, 59, 184-189. 